RESEARCH PAPER

\title{
THE EFFECT OF FLOW RATE AND TEMPERATURE ON CORROSION RATE OF CARBON STEEL PIPE IN CONDENSATE SOLUTION FROM GEOTHERMAL POWER PLANT
}

\author{
Arini Nikitasari $^{(1)}$, Ahmad Royani ${ }^{(1)}$, Gadang Priyotomo $^{(1)}$, Sundjono ${ }^{l)}$ \\ ${ }^{1)}$ Research Center for Metallurgy and Material, Indonesian Institute of Sciences, Puspiptek 470 Building, Serpong, \\ South Tangerang, Indonesia, 15313
} * Corresponding author: arininikitasari89@ gmail.com, Tel:+6285286244363, Research Center for Metallurgy and Material, Indo-
nesian Institute of Sciences, Puspiptek 470 Building, Serpong, South Tangerang, Indonesia, 15313

Received: 04.06.2021

Accepted: 26.07 .2021

\begin{abstract}
The research aims to study the effect of flow rate and temperature on the corrosion rate of carbon steel pipe in condensate solution from the geothermal power plant. The corrosion rate in this study is highlighted by electrochemical measurement. Electrochemical measurement performed in two conditions i.e stagnant and dynamic conditions. There are three kinds of temperature used in this research: $30^{\circ} \mathrm{C}, 40^{\circ} \mathrm{C}$, and $50^{\circ} \mathrm{C}$. Modification of corrosion cell installed for dynamic condition with flow rate variations: $0.27 \mathrm{~m} / \mathrm{s}$; $0.6 \mathrm{~m} / \mathrm{s} ; 1 \mathrm{~m} / \mathrm{s} ; 1.5 \mathrm{~m} / \mathrm{s} ;$ and $1.9 \mathrm{~m} / \mathrm{s}$. It was found that corrosion rate boosts with temperature and fluid flow rate in condensate solution of the geothermal power plant. The highest corrosion rate $(38 \mathrm{mpy})$ was obtained at $50^{\circ} \mathrm{C}$ and $1.9 \mathrm{~m} / \mathrm{s}$ of flow rate.
\end{abstract}

Keywords: carbon steel; flow rate; temperature; geothermal; corrosion rate

\section{INTRODUCTION}

A pipeline system is a medium for transporting steam or fluid from one area to another in the geothermal power plant. Carbon steel is widely used as a material for pipeline systems because of its economically and ability to withstand operating pressure. However, the surface of the carbon steel pipe is always exposed to a corrosive environment during the transport of steam or fluids in the process, and the integrity of the pipe system has always been found to be affected [1]. The gas content and dissolved particles in the fluid have been shown to lead an important role in the internal corrosion of the pipeline. However, other parameters such as temperature [2], fluid [3], velocity [4] and microstructure [5] have contributed to the increase in the corrosion rate of carbon steel in the geothermal power plant.

The effect of various temperatures on the corrosion rate of carbon steel has been reported [6]-[8]. Most of the studies on corrosion in oil and gas pipelines have rarely focused on aspects of flow rate and temperature in geothermal solutions. However, the flow rate is a key point and dominant parameter in the corrosion aspect [9]. In general, corrosion measurements in the field were done using the monitoring method [10], coupon [11], and corrosion probe [12]. In the laboratory, the corrosion measurement of carbon steel was determined using weight-loss [13], and polarization [14], [15] methods in a static state.

However, alternative ways are needed to predict what will happen in field conditions. Modification of cell corrosion is one approach for corrosion testing with variations in flow rates at various temperatures. With more knowledge about the process, small-scale equipment is sufficient to be used. The influence of different flow rates on the corrosion rate of carbon steel pipes at various temperatures was investigated in this work.

\section{MATERIAL AND METHODS}

\section{Sample Preparation}

The working electrodes were carbon steel from pipeline systems at the geothermal power plant. The flow diagram of specimen preparation is shown in Fig. 1. The chemical composition of the specimen showed in Table 1. Before the test, the steel pipe was cut into a cylindrical shape with $0.8 \mathrm{~mm}$ of diameter. The specimens were mounted with resin, the other side was connected by a copper wire as a connector. Then, the specimen surfaces were polished with $80,120,320$, and 400 grit $\mathrm{SiC}$ paper, rinsed with acetone. The test was repeated at least twice to ensure reasonable reproducibility.

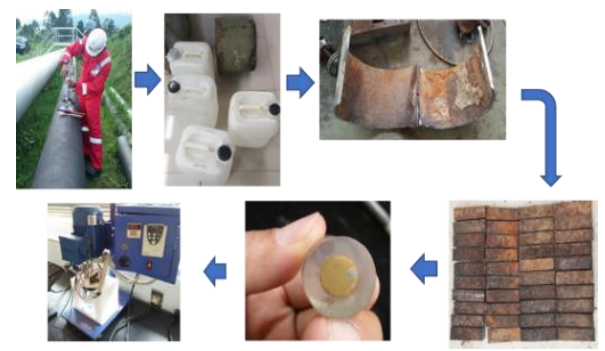

Fig. 1 The flow diagram of experimental

Table 1 Chemical Composition of Specimen

$$
\text { Element (\% w.t) }
$$

\begin{tabular}{ccccccccccc}
\hline Fe & C & Cr & Ni & Mn & Mo & Al & Si & Cu & S & P \\
\hline Bal & 0.09 & 0.01 & 0.02 & 0.99 & 0.01 & 0.03 & 0.24 & 0.008 & 0.004 & 0.02
\end{tabular}


Electrochemical set-up

A design schematic of the three-electrode used in all electrochemical experiments is presented in Fig. 2. A rotating cylinder electrode (RCE) with speed control and temperature control was used as a modification of the working electrode. Glass cell was fitted with platinum electrodes as an auxiliary electrode (counter electrode) and calomel as a reference electrode.

Simulation of flow conditions was conducted using a rotating cylinder electrode (RCE). A specimen (working electrode) was screwed onto an electrode holder at the centre of the cell. The potentiodynamic polarization (Tafel) technique was used to measure corrosion rate. The procedure of all experiments is based on the ASTM standard test G5-94.

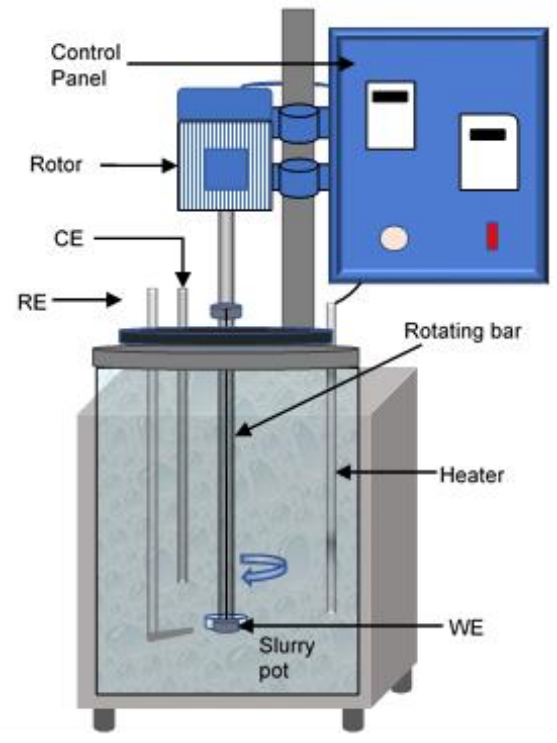

Fig. 2 Schematic of Rotating Cylinder Electrode (RCE)

\section{Cell Solution}

The experiments were carried out both in stagnant and flow solution conditions. Glass cell filled with $1 \mathrm{~L}$ of condensate solutions from the pipeline of the geothermal power plant. The parameter of the condensate solution showed in Table 2. The temperature of the solution was set using a thermocouple and temperature control. After the solution was checked, the specimen was put in the solution, and then the glass cell was closed.

Table 2 Parameter of Condensate Solution

\begin{tabular}{cccccccc}
\hline $\begin{array}{c}\mathrm{DO} \\
(\mathrm{mg} / \mathrm{l})\end{array}$ & $\begin{array}{c}\mathrm{TDS} \\
(\mathrm{mg} / \mathrm{l})\end{array}$ & $\begin{array}{c}\text { Conduc } \\
(\mu \mathrm{S} / \mathrm{cm})\end{array}$ & $\begin{array}{c}\text { Salinity } \\
(\%)\end{array}$ & $\mathrm{pH}$ & $\begin{array}{c}\text { Temp } \\
\left({ }^{\circ} \mathrm{C}\right)\end{array}$ & $\begin{array}{c}\text { Ca Hard } \\
(\mathrm{ppm})\end{array}$ & $\begin{array}{c}\text { Total } \\
\text { Alkal } \\
(\mathrm{ppm})\end{array}$ \\
\hline $\mathbf{6 . 4 1}$ & 161.6 & 338 & 0.16 & 4.68 & 27.4 & 1 & 3.7 \\
\hline
\end{tabular}

\section{Test Condition}

In this study, the test condition for corrosion measurement will be performed under stagnant and dynamic conditions. The parameter of tests is temperature and flow solutions. The variation of temperature solution is $30{ }^{\circ} \mathrm{C}, 40{ }^{\circ} \mathrm{C}$, and $50{ }^{\circ} \mathrm{C}$, and flow solution are $0 \mathrm{~m} / \mathrm{s} ; 0.27 \mathrm{~m} / \mathrm{s} ; 0.6 \mathrm{~m} / \mathrm{s} ; 1.09 \mathrm{~m} / \mathrm{s}$; $1.5 \mathrm{~m} / \mathrm{s} ;$ and $1.9 \mathrm{~m} / \mathrm{s}$, respectively.

A cylindrical pipe steel specimen was sequentially polished with 80, 120, 320 and 400 grit SiC rinsed with alcohol, and air- dried. It was then mounted onto the RCE rotator and inserted into the glass cell for electrochemical measurements. The RCE was set to the desired rotational speed and the corrosion measurements were initiated. Electrochemical measurements were conducted using a three-electrode setup with a mild steel rotating cylinder (RCE) as the working electrode (WE). A platinum mesh plate was used as the counter electrode (CE). Calomel was used as a reference electrode (RE). Open circuit potential (OCP), measurements were done first to ensure that a reasonably stable state was reached, where the OCP drift was less than $1 \mathrm{mV}$ per min and the magnitude of the OCP fluctuation was less than $1 \mathrm{mV}$. The OCP measurements were immediately followed by potentiodynamic polarization. Potentiodynamic polarization measurements were performed via sweeping potential from $-250 \mathrm{mV}$ versus OCP to $+250 \mathrm{mV}$ versus OCP with a scan rate of $1 \mathrm{mV} / \mathrm{s}$. All of the experiments underflow and static conditions were repeated three times in this work.

The corrosion products on the sample surface were observed using visual observation to compare the effect of flow rate and temperature on corrosion resistance of the sample.

\section{RESULTS AND DISCUSSION}

\section{The Effect of Temperature on Corrosion Rate in Static Condition}

Fig. 3 shows the polarization curves of pipe steel in the condensate solution from a geothermal power plant at various temperatures. It can be found that the cathode current density is lower when the process is at room temperature $\left(30^{\circ} \mathrm{C}\right)$. As it can be seen, the cathodic curve (hydrogen evolution reaction) was accelerated by increasing temperature while anodic curves showed similar current densities. With the increase in the temperature solution, the self-corrosion current density ( $\left.\mathrm{I}_{\text {corr }}\right)$ and the cathodic current density increase gradually. However, the temperature has little effect on the anodic current density. This anodic curve is related to the dissolution of iron.

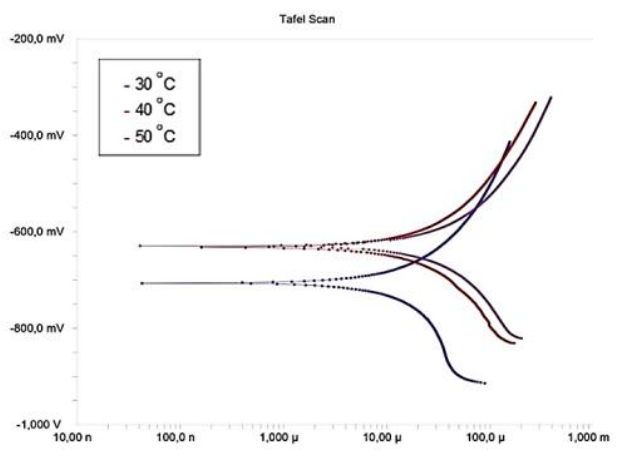

Fig. 3 Polarization Curves of Carbon Steel Pipe in Different Temperatures under Stagnant Conditions

The corrosion rate of carbon steel pipe in condensate solution at different temperatures are shown in Fig. 4. Based on Fig. 4, the corrosion rate of carbon steel pipe increase with increasing the temperature of the solution. This result is in agreement with the theory which states that temperature can increase the corrosion rate as a result of an increase in the rate of electrochemical and chemical reactions as well as the diffusion rate [16]. The diffusion rate of ions contained in geothermal 
solution such as hydrogen and oxygen will increase when the solution temperature increase following Arrhenius Law:

$D_{i}=D_{i o} \cdot e^{\left[\frac{Q}{R \cdot T}\right]}$

Where,

Di = diffusion coefficient $\left(\mathrm{m}^{2} / \mathrm{s}\right)$

Dio $\quad=$ pre-exponential diffusion $\left(\mathrm{m}^{2} / \mathrm{s}\right)$

$\mathrm{Q}=$ activation energy for diffusion $(\mathrm{J} / \mathrm{mol})$

$\mathrm{R} \quad=$ gas constant $(8.314 \mathrm{~J} / \mathrm{mol} . \mathrm{K})$
$\mathrm{T}=$ absolute temperature $(\mathrm{K})$

The increasing of hydrogen and oxygen diffusion boost the cathodic reaction:

$4 \mathrm{H}^{+}+\mathrm{O}_{2}+4 \mathrm{e}^{-} \rightarrow 2 \mathrm{H}_{2} \mathrm{O}$

Therefore, cathode current density based on the polarization curve was increased and improve the corrosion rate by increasing temperature.

Table 3 The Result of Liquid Quality Parameters of Condensate Solution

\begin{tabular}{|c|c|c|c|c|c|c|c|}
\hline Temp. ${ }^{\circ} \mathrm{C}$ & $\begin{array}{c}\text { Chec] } \\
\text { tim } \\
\text { e }\end{array}$ & $\begin{array}{c}\text { DO } \\
(\mathrm{mg} / \mathrm{L})\end{array}$ & TDS (mg/L) & $\begin{array}{l}\text { Conductivity } \\
\quad(\mathrm{uS} / \mathrm{cm})\end{array}$ & $\begin{array}{c}\text { Salinity } \\
(\%)\end{array}$ & $\mathbf{p H}$ & Temp. ${ }^{\circ} \mathrm{C}$ \\
\hline \multirow[t]{3}{*}{30} & 0 & 6.41 & 161.6 & 338 & 0.16 & 4.68 & 27.4 \\
\hline & 1 & 6.59 & 165 & 345 & 0.17 & 4.45 & 29.2 \\
\hline & 2 & 6.25 & 171 & 358 & 0.18 & 4.78 & 30.2 \\
\hline \multirow[t]{3}{*}{40} & 0 & 5.94 & 140.2 & 293 & 0.14 & 3.96 & 39.7 \\
\hline & 1 & 5.78 & 141.7 & 299 & 0.14 & 4.01 & 39.2 \\
\hline & 2 & 5.69 & 143.6 & 300 & 0.14 & 4.14 & 40.2 \\
\hline \multirow[t]{3}{*}{50} & 0 & 5.62 & 141 & 295 & 0.14 & 4.06 & 47.4 \\
\hline & 1 & 5.3 & 142.7 & 298 & 0.14 & 4.05 & 48.3 \\
\hline & 2 & 5 & 144.7 & 302 & 0.14 & 4.09 & 48.9 \\
\hline
\end{tabular}

Table 3 shows the results measurement of liquid quality parameters of condensate. it shows that there is no significant change of parameter in all tests. These results indicate that the condensate solution is still good for use in repeating the test. Research has shown that at higher temperatures (above than $30^{\circ} \mathrm{C}$ ), the temperature can play an important role in increasing corrosion rates due to improved hydrogen evolution reaction rates [17].

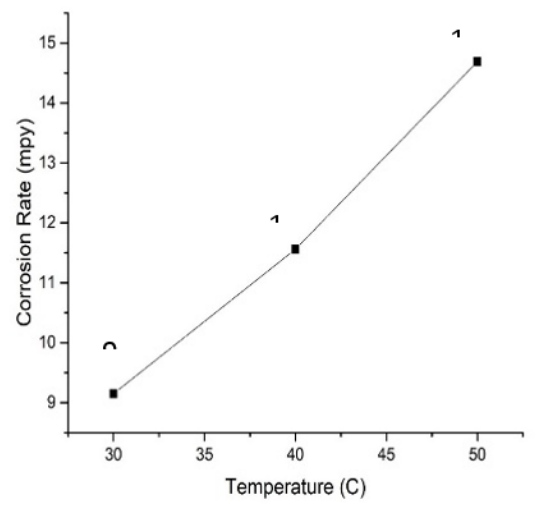

Fig. 4 Corrosion Rate of Carbon Steel Pipe in Condensate Solution at Different Temperatures under Stagnant Condition.

The Effect of Temperature on Corrosion Rate in Dynamic Condition

Figs. 5a-5c shown the typical potentiodynamic polarization curve of carbon steel pipe in condensate solution with $0.6 \mathrm{~m} / \mathrm{s}$, $1 \mathrm{~m} / \mathrm{s}$, and $1.6 \mathrm{~m} / \mathrm{s}$ at various temperatures. Fig. 5 obtained that corrosion potential $\left(\mathrm{E}_{\text {corr }}\right)$ value at $30{ }^{\circ} \mathrm{C}$ is more noble than corrosion potential at 40 and $50^{\circ} \mathrm{C}$. Generally, the more noble corrosion potential the more resistant to corrosion attack. In other words, corrosion rate increase with the increase of temperature in each flow rate based on Fig. 5.

Although the corrosion potential has optimum values at $30^{\circ} \mathrm{C}$, the corrosion current at this temperature is lower than the corrosion current at 40 and $50^{\circ} \mathrm{C}$. The anodic currents at 40 and $50^{\circ} \mathrm{C}$ are high as the potential was scanned from OCP in the anodic direction which confirms that the corrosion rate of the steel was affected by temperature [8].

Táel scan

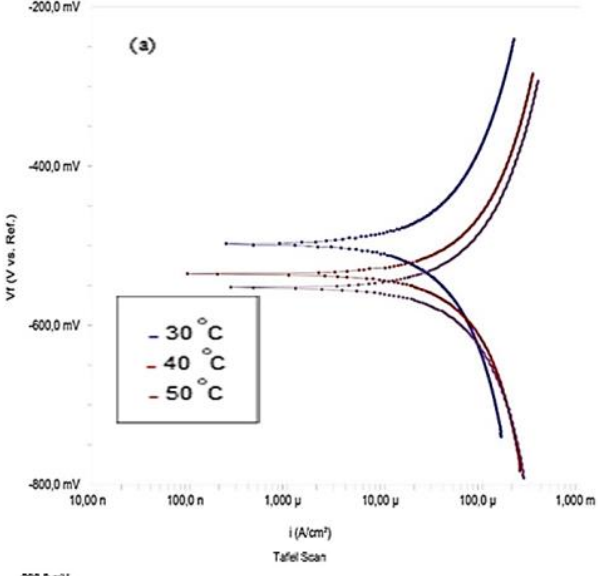

$\cdot 2000 \mathrm{mV}$

(b)

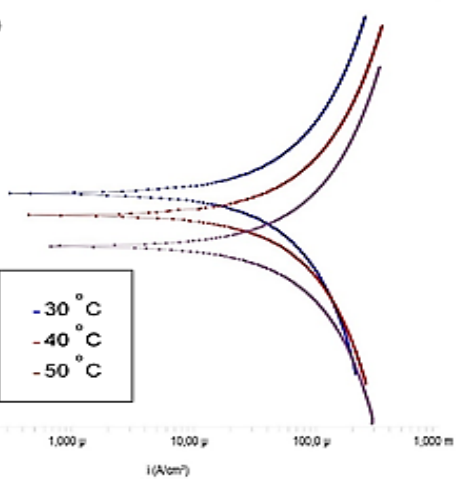




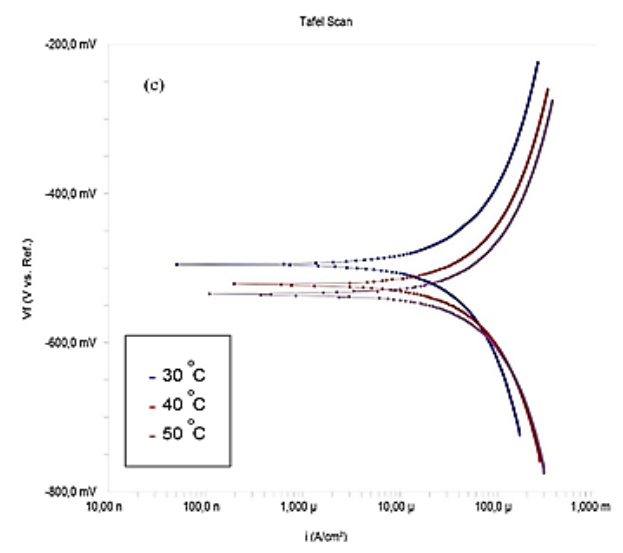

Fig. 5 Polarization Curve of Carbon Steel Pipe in Condensate Solution with Flow rate (a) $0.6 \mathrm{~m} / \mathrm{s}$, (b) $1 \mathrm{~m} / \mathrm{s}$, and (c) $1.6 \mathrm{~m} / \mathrm{s}$

The increase in the corrosion currents at 40 and $50^{\circ} \mathrm{C}$ compared to $30^{\circ} \mathrm{C}$ which are almost the same is attributed to the $\mathrm{pH}$ in the solution. According to Table 3, pH solution at $30^{\circ} \mathrm{C}$ was greater than $\mathrm{pH}$ solution at 40 and $50^{\circ} \mathrm{C}$. Increasing the temperature from 30 to $50{ }^{\circ} \mathrm{C}$, lowered the $\mathrm{pH}$ slightly due to the hydrolysis process of the dissolved $\mathrm{Fe}$ ions [7]. In a dynamic condition, corrosion rate increase with increasing the temperature as in stagnant condition. An increase in temperature impelled ions activities in the condensate solution which enhanced the corrosion rate [8].

\section{The Effect of Flow Rate on Corrosion Rate in Dynamic \\ Condition}

The experimental results of various flow rates were shown in Fig. 6. Fig. 6 shows the Tafel curve polarization of carbon steel pipe measured in a condensate solution with a variation of the flow rate of $0 \mathrm{~m} / \mathrm{s} ; 0.27 \mathrm{~m} / \mathrm{s} ; 0.6 \mathrm{~m} / \mathrm{s} ; 1 \mathrm{~m} / \mathrm{s} ; 1.5 \mathrm{~m} / \mathrm{s}$; and 1.9 $\mathrm{m} / \mathrm{s}$ at different temperature. In Fig. 6, it can be seen that the shift in the value of the corrosion potential is more positive, with increasing rotation speed from $0 \mathrm{~m} / \mathrm{s}$ to $1.9 \mathrm{~m} / \mathrm{s}$. This indicates that the steel dissolving activity increases with the acceleration of the rotating speed.

The results of the analysis of all polarization curves in Fig. 6 using the Echem Analyst Software from Gamry are shown in Table 4. Table 4 shows that the corrosion potential value ( $\left.E_{\text {corr }}\right)$ increases with increasing rotation speed, as well as the corrosion

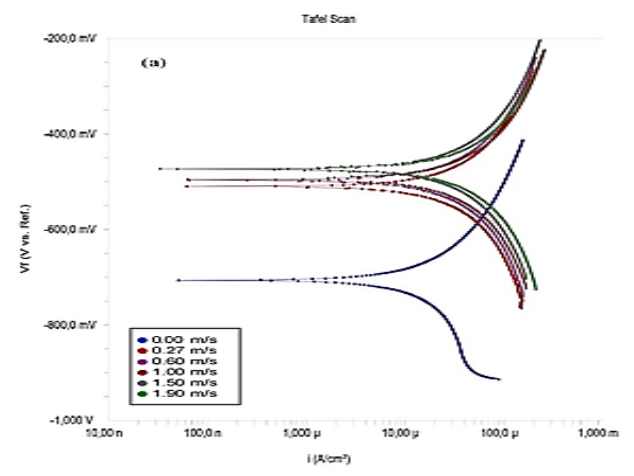

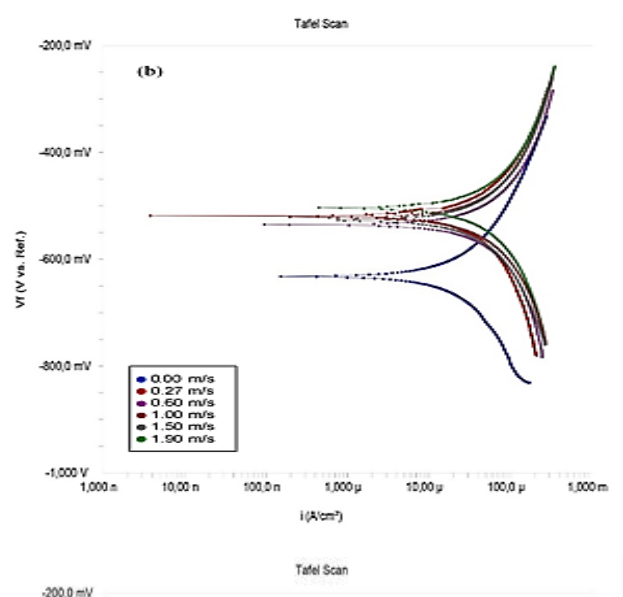

(c)

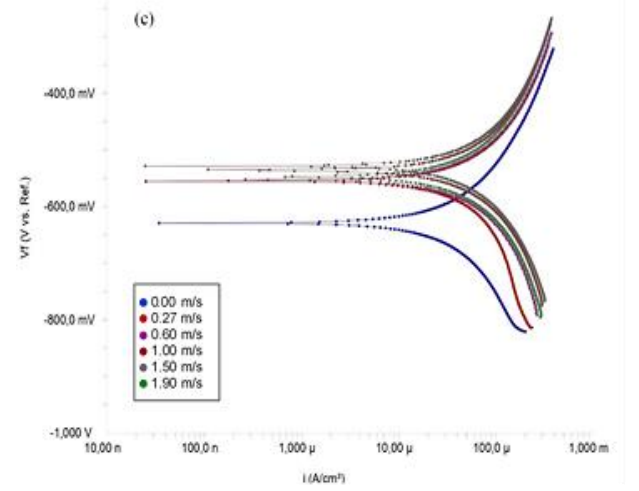

Fig.6 Polarization Curve of Carbon Steel Pipe in Different Flow rate at (a) $30^{\circ} \mathrm{C}$, (b) $40^{\circ} \mathrm{C}$, and (c) $50^{\circ} \mathrm{C}$

current value $\left(\mathrm{I}_{\text {corr }}\right)$ increases with increasing rotation speed. This shows that increasing the rotation speed increases the dissociation of the corrosive element in the solution, and reduces the thickness of the diffusion layer so that it also reduces the resistance of the steel reaction with the environment.

In addition, an increase in the rotation speed can affect the dissolution of corrosion products [18], so that the supply of $\mathrm{H}^{+}$ ions to the steel surface is not hindered by corrosion products. The increase in rotation speed affects the breaking of air bubbles adhering to the steel surface, where this phenomenon can be seen when the experimental observation is carried out. As a result, increasing the rotation speed will increase the corrosion current density ( $\mathrm{I}_{\text {corr }}$ ) and the corrosion rate. In addition, Table 5 shows that the $\mathrm{E}_{\text {corr }}$ value increases with increasing rotation speed. This can be explained by an increase in the supply of $\mathrm{H}^{+}$ions to the metal surface due to an increase in the rotational rate so that it attracts more electrons and increases the dissolution of the steel. Therefore, the corrosion reaction on the metal surface increases and $\mathrm{E}_{\text {corr }}$ increases, because the potential value is directly proportional to the electric charge with the potential [19]. Literature and reports have shown that flow rate and fluid composition can play a role in corrosion rates [3], [4], [6], [9], [20]. The turbulence flow fluid appears to increase and severe to corrosion [21]. 
Table 4 The Value Results of Ecorr and Icorr

\begin{tabular}{|c|c|c|c|c|c|c|}
\hline \multirow{2}{*}{ Flow $(\mathrm{m} / \mathrm{s})$} & \multicolumn{2}{|c|}{$30^{\circ} \mathrm{C}$} & \multicolumn{2}{|c|}{$40^{\circ} \mathrm{C}$} & \multicolumn{2}{|c|}{$50^{\circ} \mathrm{C}$} \\
\hline & Ecorr $(\mathbf{m V})$ & $\operatorname{Icorr}\left(\mathbf{A} / \mathrm{cm}^{2}\right)$ & Ecorr $(\mathrm{mV})$ & $\operatorname{Icorr}\left(\mathbf{A} / \mathrm{cm}^{2}\right)$ & Ecorr $(\mathbf{m V})$ & $\operatorname{Icorr}\left(\mathbf{A} / \mathrm{cm}^{2}\right)$ \\
\hline $\mathbf{0}$ & -706.6 & $2.00 \mathrm{E}-05$ & -632.0 & $2.58 \mathrm{E}-05$ & -629.0 & $3.81 \mathrm{E}-05$ \\
\hline 0.27 & -509.9 & $3.99 \mathrm{E}-05$ & -535.0 & $5.31 \mathrm{E}-05$ & -555.3 & $7.42 \mathrm{E}-05$ \\
\hline 0.6 & -496.7 & $4.29 \mathrm{E}-05$ & -519.8 & $7.33 \mathrm{E}-05$ & -552.8 & $8.12 \mathrm{E}-05$ \\
\hline 1.09 & -473.1 & $4.59 \mathrm{E}-05$ & -503.3 & $7.27 \mathrm{E}-05$ & -547.6 & $8.36 \mathrm{E}-05$ \\
\hline 1.5 & -495.1 & $4.87 \mathrm{E}-05$ & -522.1 & $7.51 \mathrm{E}-05$ & -535.2 & $8.39 \mathrm{E}-05$ \\
\hline 1.9 & -473.0 & $5.02 \mathrm{E}-05$ & -527.9 & $7.67 \mathrm{E}-05$ & -528.2 & $8.95 \mathrm{E}-05$ \\
\hline
\end{tabular}

The results of the mean interpretation on the corrosion rate of carbon steel pipes with various flow rates at different temperatures were shown in Fig. 7. The corrosion rate of carbon steel is influenced by the flow rate and temperature of the liquid. From the calculation result (current corrosion), the corrosion rate of pipe steel was is around $8 \mathrm{mpy}$ at $30^{\circ} \mathrm{C}$ in static conditions. In the static test condition, the general corrosion rate of pipe steel was near $15 \mathrm{mpy}$ at $50{ }^{\circ} \mathrm{C}$.

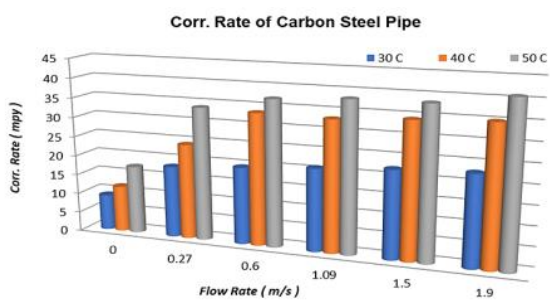

Fig. 7 The Corrosion Rate of Carbon Steel in Different Flows at Various Temperatures

Fig. 7 shows the effect of temperature on the corrosion rate in dynamic conditions. It is interesting to note that when continuing to increase the flow rate, the general corrosion rate is relatively constant from $1.5 \mathrm{~m} / \mathrm{s}$ to $1.9 \mathrm{~m} / \mathrm{s}$. The highest results

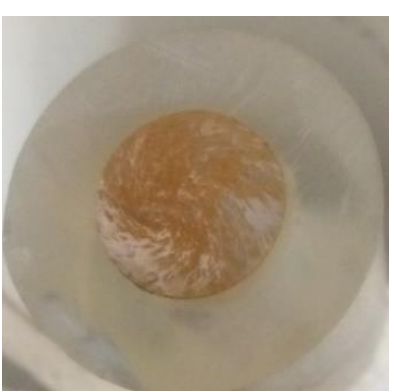

$30{ }^{\circ} \mathrm{C}$

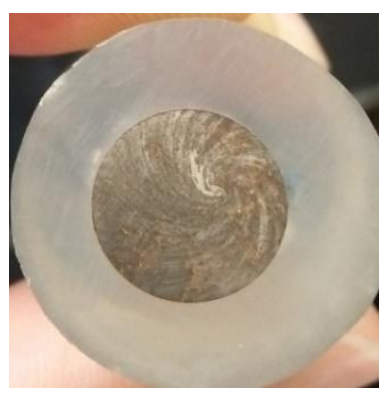

$40{ }^{\circ} \mathrm{C}$ of corrosion rate were obtained in dynamic aqueous is 21,34 , and $38 \mathrm{mpy}$ at 30,40 , and $50{ }^{\circ} \mathrm{C}$ with $1.9 \mathrm{~m} / \mathrm{s}$. With the increase of the temperature and flow liquid, the corrosion rate increased accordingly and reached the maximum of about 38 mpy with a temperature of about $50^{\circ} \mathrm{C}$.

\section{Corrosion Product}

Corrosion product of carbon steel pipe in condensate solution from geothermal plant investigated by visual observation. Visual observation of specimens with flow rate $1 \mathrm{~m} / \mathrm{s}$ at various temperatures are shown in Fig. 8. Images captured by a digital camera showed the formation of corrosion products in a colloidal form. It was observed the formation of some gravures occurred on the carbon steel surface due to the reaction of the steel specimen with the condensate solution in a colloidal form and can be ascribed to the effect of flow rate on the specimen [8].

The corrosion product was darker at higher temperatures as presented in Fig. 8. This result proves that corrosion rate increase with increasing temperature in dynamic condition. The black colour of corrosion product formed on steel surface at $50^{\circ} \mathrm{C}$, brown colour at $40^{\circ} \mathrm{C}$, and yellow colour formed at $30^{\circ} \mathrm{C}$. The darker colour of the corrosion product indicated that the corrosion product was denser and more abundant as a result of a more severe corrosion reaction.

Fig. 8 The Visual Observation in Flow rate $1 \mathrm{~m} / \mathrm{s}$ at Various Temperatures

\section{CONCLUSION}

Temperature and flow rate has an important role in the corrosion rate of carbon steel pipe in condensate solution from a geothermal power plant. By increasing the temperature, the corrosion rate increased under static and dynamic conditions. Flow rate enhances the corrosion rate at each temperature. These results were corroborated by visual observation. According to visual observation, the increase of temperature from the darker corrosion product is a result of a more severe corrosion attack.

\section{ACKNOWLEDGMENTS}

The authors would like to gratitude to Research Center for Metallurgy and Material of the Indonesian Institute of Sciences for providing laboratory facilities and funding this research.

\section{REFERENCES}

1. T. Kaya, P. Hoshan: Corrosion and Material Selection for Geothermal Systems, In.: World Geothermal Congress, Vol. 1, 2005, 460-464.

2. X.H. Nie, X.G. Li, C.W. Du, Y.F. Cheng: J. Appl. Electrochem, 39(2), 2009, 277-282. https://doi.org/10.1007/s10800008-9669-1.

3. K. Denpo, H. Ogawa: Corrosion, 49(6), 1993, 442-449. 
https://doi.org/10.5006/1.3316070.

4. Y. Zhao, et.al.: Corros. Sci, 145, 2018, 307-319.

https://doi.org/10.1016/j.corsci.2018.10.011.

$5 . \quad$ N. Pomerantz, Y.H. Ma: Underst. Biocorrosion Fundam. Appl, 1(5), 2014, 385-407.

6. P. Sui, C. Sun, Y. Hua, J. Sun, Y. Wang: The Influence of Flow Rate on Corrosion Behavior of X65 Carbon Steel in Water-saturated Supercritical CO2/H2S System. In.: NACE Int. Corros. Conf. Series, 13081, 2019.

7. P.C. Okonkwo, M.H. Sliem, R.A. Shakoor, A.M.A. Mohamed, A.M. Abdullah: J. Mater. Eng. Perform., 26(8), 2017, 3775-3783.

https://doi.org/10.1007/s11665-017-2834-0.

8. A. Benamor, A.G. Talkhan, M. Nasser, I. Hussein, P.C. Okonkwo: J. Electroanal. Chem, 808, 2018, 218-227. https://doi.org/10.1016/j.jelechem.2017.12.009.

9. J.H. Kim, I.S. Kim: Journal of the Korean Nuclear Society, 32(6), 2000, 595-604.

https://doi.org/10.1016/j.jelechem.2017.12.009.

10. J. Villavicencio, N. Ulloa, L. Lozada, M. Moreno, L. Castro: J. Mater. Res. Technol, 9(3), 2020, 5894-5911.

https://doi.org/10.1016/j.jmrt.2020.03.116.

11. A. Nikitasari, G. Priyotomo, A. Royani: Int. J. Corros. Scale Inhib, 9(2), 2020, 745-756.

https://doi.org/10.17675/2305-6894-2020-9-2-22.

12. D. A. Jones: Principles and Prevention Corrosion, 2.ed, Prentice Hall, New Jersey, USA, 1996.

13. F. Hashim, K. Al-Azawi, S.B. Al-Baghdadi, L.M. Shaker, A. Al-Amier: Proceedings, 41(1), 2019, 15.

https://doi.org/10.3390/ecsoc-23-06477.

14. Y. Zheng, B. Brown, S. Nešić: Corrosion, 70(4), 2014, 351-365. https://doi.org/10.5006/0937.

15. Y. Zheng, J. Ning, B. Brown: Corrosion, 71(3), 2015, 316-325. http://doi.org/10.5006/1287.

16. P.A. Schweitzer: Fundamentals of Metallic Corrosion, 2 ed, CRC Press, New York, USA, 2006. https://doi.org/10.1201/9780849382444.

17. L.E. García: J. Chem. Inf. Model, 53(9), 2013, 1689-1699.

18. L.Q. Aké, R.C. Sierra, E.A. Estrada, J.M. Cruz: Int. J. Electrochem. Sci., 3(1), 2008, 56-66.

19. Z. Ahmad: Corrosion Engineering and Corrosion Control, Elsevier Science \& Technology Books, Oxford, UK, 2006, ISBN: 0750659246.

20. S.A. Peralta, J.M. Florez, R.D. Romero: Corros. Sci. Eng. Tech, 41(4), 2006, 321-327.

https://doi.org/10.1179/174327806X139117.

21. K.J. Hwan, K.I. Sup: Journal of the Korean Nuclear Society, 32(6), 2000, 595-604. 